\title{
EXPLORING THE URBAN HYDROSOCIAL CYCLE IN TOURIST ENVIRONMENTS ${ }^{1}$
}

\author{
Elena Ridolfi \\ Departament of Geography, Barcelona, \\ Universitat Autònoma de Barcelona, Spain.
}

\begin{abstract}
This contribution attempts to examine first how different theoretical and methodological perspectives from Geography and environmental sciences explore water flows and their physical and social dimensions in the city, as well as their changes in response to the emerging urban complexities and challenges. Using in particular the framework provided by Urban Political Ecology, I look at how the physical and social dimensions of water flows unfold and influence the urbanization process and, in turn, are influenced by urbanization. In the second part, attention is paid to urban coastal areas of the Mediterranean as candidate laboratories of analysis under urban political ecology since they are subject to rapid processes of social environmental change in which water plays a fundamental part. Case studies included to examine physical and social dimensions of water flows include heritage towns (Venice) and mass tourism resorts (Benidorm).
\end{abstract}

Keywords: Hydrosocial cycle, water, governance, Urban Political Ecology, tourism, Mediterranean region.

\section{RESUMEN}

\section{Explorando el ciclo urbano hidrosocial en entornos turísticos}

Esta contribución intenta examinar primero cómo diferentes perspectivas teóricas y metodológicas de la geografía y las ciencias ambientales exploran los flujos de agua en sus dimensiones física y social en la ciudad, así como sus modificaciones, en respuesta a las complejidades y desafíos urbanos emergentes. A través del marco establecido por la disciplina de la Ecología Política Urbana, miro cómo las dimensiones físicas y sociales de los flujos de agua se desarrollan e influyen en el proceso de urbanización y, a su vez, se ven influenciada por la urbanización. En la segunda parte, se presta atención a las zonas urbanas costeras del Mediterráneo como laboratorios candidatos de análisis en el marco de ecología política urbana, ya que están sujetas a rápidos procesos de cambio social y ambiental en el que el agua juega un papel fundamental. Los estudios de caso incluidos para examinar las dimensiones físicas y sociales de los flujos de agua incluyen la ciudad cultural de Venecia y el destino turístico de masas de Benidorm.

Palabras clave: Ciclo hydrosocial, agua, gobernanza, Urban Political Ecology, turismo, región Mediterránea.

Contacto: elena.ridolfi.ueir@gmail.com

1 This work is the result of a preliminary research conducted for the preparation of a PhD's thesis in Geography, Spatial Planning and Public Policies; supported by the PhD scholarship, number FI_B 00773, of the Agency for Management of University and Research Grants of Catalonia (AGAUR), the Comisionado para Universidades e Investigación (CUR), the Departamento de Innovación, Universidades y Empresa (DIUE) and the European Social Fund.

An earlier version of this paper was presented to the GRATS Research Seminar in the section "Physical and social flows of urban water in the Mediterranean: from past to present" held at the Universitat Autònoma de Barcelona, Spain, on 10-11 June, 2013. 


\section{INTRODUCTION}

Water remains a vital flow for the formation, growth and development of every urban settlement (UNHABITAT, 2011). It is considered part of the complex web of relations between society and nature (Gandy, 1997) and one medium of social relations (Linton, 2010) through which urbanization will progress, thrive or decline (UN-HABITAT, 2011).

In coastal cities, possibly the most urbanized and populated areas around the world, water has played, and continues to play, an important role in determining urban expansion and transformation and sustaining the functions which depend on these trends. Tourism, one of the most growing global economic sectors, already represents a fundamental economic strategy of urban development for many of these cities that tends to diversity and specialize. Several western coastal cities have transformed themselves into important tourist destinations, with new urban patterns and tourist models. As tourism and others global forces of socio-environmental change are increasingly taking place in cities, new urban developments to accommodate people, activities and infrastructures will be needed. These developments will generate new urban configurations or will adapt themselves through new functions. The tapping of new water resources or the increased use of existing ones are key elements to sustain such needs. However, as Page and Hall (2003) have noted the scale, complexity and diversity of consumption characterizing these new urban configurations are leading to a growing concern with regard to actual and potential pressures on existing social and natural resources such as water. In this regard Gössling et al. (2012) argue that although direct tourism-related urban water use will not become significant even if the sector continues to grow, the situation may differ at regional level because tourism is concentrated in time and space, and often in destinations where water resources may be limited. This is particularly the case of many cities of the Mediterranean region where water is «a vital resource» but also «increasingly scarce and limited» (UNEP/MAP-Plan Bleu, 2009). Here tourism attracts a large concentration of visitors and is already the most important economic sector (UNWTO, 2012). It in large part influences urbanization and new urban forms and amenities (e.g. swimming pools, golf courses) which are highly dependent on water resources and that would be unavailable without it (Rico-Amoros et al., 2009; Gössling, 2006, 2012). Physical and social factors are therefore raising special concerns regarding new uses, production, practices, management and control of urban water flows which are intensifying and posing major challenges of governance in the Mediterranean region, and elsewhere.

The main task of this paper is to explore the characteristics of water flows in coastal cities, increasingly specialized and diversified by tourism. For a long time, as the paper outlines below, flows of water have been discussed and treated from a physical perspective. First they were represented and conceptualized by scientists and engineers through the 'hydrologic cycle'; a diagram tracing and explaining the process of natural water flow and its circulation in the environment. Then, through the «urban»- «hydrological cycle», also called «urban water cycle» the integration between «the natural and managed pathway that water follows in an urban ecosystem» (PAP/RAC, 2007) was sought after. This interaction was conceptualized by observing the increasing relationships between water and urban areas, in order to ensure water services to the urban population and to cope with emerging urban water-related problems (UNESCO, 2006:3). Nevertheless, in the last decades, as rapid processes of global socio-environmental changes have made the urban system more complex, social scientists have observed that physical approaches and models of water management, have led towards a fundamental separation between the nature of water and its social context. Therefore, it was no longer sufficient to deal with present and future urban water challenges. From the social sciences came the idea that water in urban environment is not just a physical entity or a quantification matter, but rather a social issue (Linton, 2010). Geographers, in particular, have critically focused on the «socio-ecological nature of water». On the one hand, questions have been raised attempting to address the problems of water in the environment and in urban systems. On the other hand, the concept of «hydrosocial cycle», which incorporates newer approaches drawn from water political ecology and social studies of science, has been adopted (Budds, 2008, 2009; Kaika, 2005; Linton, 2008, 2010; Swyngedouw, 2004). From this perspective the hydrosocial cycle is defined as «the sum of the human and physical interrelationships pertaining to water in cities» (Keil and Young, 2001:1), attempting to show how the social, political, cultural, and economic systems govern the flow of water through societies (see for example: Swyngedouw 2004, 2005; Bakker 2002; Swyngedouw et al., 
2002). In practice, the study of the hydrosocial cycle in urban areas involves a «big picture» «tracing the flow of water and examining the physical and socio-political discourses surrounding it, to illuminate the functioning of urban space in all its complexity and contradictions» (Gandy, 1997:339). While much research on water has been conducted from a physical perspective, recently a growing number of contributions have tended to analyze its social dimensions. As this paper will attempt to show, practical applications of hydrosocial cycle concept on case studies selected worldwide are emerging. The review of these cases reveal that the concept remains in theoretical and practical terms, not fully defined, and is likely to become case dependent (Bardati, 2009; Fonstad, 2013). Furthermore, the variety of approaches and methods can also bewilder water researchers and practitioners (Fonstad, 2013). However, new dialectical discourses and representations of the hydrosocial cycle open new windows to scrutinize water politics and governance. Starting from these premises, this paper asks how the concept of hydrosocial cycle may help to analyze, trace and assess physical and social water flows and their governance in tourist coastal cities.

After framing the co-evolving relations between water and urbanism, their complexity and new challenges for governance, the first objective of this paper is to review the development of the hydrosocial cycle concept largely through academic research and previously published studies. This part endeavors to elucidate what we know about this concept and how it continues to change over time.

Second, the paper reflects how and to what extent this concept could be extended to hydrosocial cycle in urban tourist contexts. The cases of Venice (Italy) and Benidorm (Spain) are briefly presented in this respect as paradigmatic tourist coastal cities of the Mediterranean and very relevant to investigate the specific applicability of this concept.

The paper concludes by stressing the main results that have emerged from this study, and the potential to extend the hydrosocial cycle to urban tourist cities for further new ideas and representations of water governance in tourist urban areas.

\section{WATER AND URBANISM: CO-EVOLVING RELATIONS, COMPLEXITY AND NEW GOVERNANCE CHALLENGES}

"It is the interaction between these two ecosystems (water and the city) that is both complex and fascinating.»

Timmerman and White (1997)

Since ancient times water and urban environments have co-evolved continuously through complex interrelationships that are temporally contingent, spatially variable, and shifting through nonlinear processes and rates, giving rise to new urban and resource configurations. In recent centuries such interrelationships have intensified significantly becoming closely interlinked since urban communities have become even more dependent on water: first for the satisfaction of their basic needs and then for the increase in the large scale production and consumption of water-based goods and services (Castro, 2013). According to the latest World Water Development Report (UNESCO-WWAP, 2012) as the world's population is growing by about 80 million people a year, freshwater demand is increasing accordingly: about 70 percent of the world's water is used for irrigation, 20 percent for industry, and about 10 percent for domestic use, including new economic sectors like tourism. In the last century world water use has increased by six times, and between 1900 and 1995 at global level, the increase has more than doubled the rate of population growth. At the same time, urbanization and globalization process have been accompanied by profound changes in socio-political and cultural systems, economic power, environmental contexts, and by the development of several forms of social interaction at all levels (Goudsblom, 1992; De Vries and Goudsblom, 2002). Cities, more than rural areas, have captured all these changes and also the socioenvironmental problems associated (UN-Habitat, 2012).

According to the Final Report of the United Nations Human Settlements on water and urbanization (UNHabitat, 2011) in a rapidly changing and urbanizing world, the dimension of water has become complex. Although the term «complexity» seems a recent feature of contemporary cities, Batty and Marshall (2012) highlight that urban complexity was observed already in the past by different social scholars. Geddes, 
for example, one of the first town planner pioneers that dealt with urban complexity, noted that «towns or cities are a mixture of urban elements that grew out in a complex web of causes and effects and its interrelated parts interwoven throughout time» (Batty and Marshall, 2012: 24). Van der Brugge et al. (2007) argue that complexity about water problems is generated by the economic, ecological and social functions of water; and because water differs in time, place and manifestations, represents multiple values, is characterized by different forms (e.g. rainwater, groundwater, surface water, sea water) that manifest in different issues (e.g. water scarcity, and the alteration of the hydrological cycle). These authors argue that water problems are deeply rooted in the new types of societal structures and institutions characterized by significant complexity, uncertainty, and the high stakes for the wider diversity of stakeholders involved. They also add that the complexity of the interactions of broad societal trends (characterized by significant complex societal interactions, structures and institutions) and physical (natural) processes lead to problems of management and governance of water. In this regard, Castro (2013) and Peña García (2007) note how human societies have established different forms of control over water to govern, allocate and manage this resource and political and economical decisions also have determined social relations with water. Norman et al. (2012) state that the complex interconnections of human-environmental issues, and more specifically the complex nature of flow resources such as water, continue to complicate and challenge current governance systems. In this connection, all the talk about the «water crisis», of the last decade, has been recognized as a "crisis of governance» (GWP, 2000), for the lack of proper consideration of the social, cultural, economic, environmental and political dimensions in which water is embedded (Rogers and Hall, 2003).

However, new recognitions about the social dimension of water are emerging and opening new perspectives to beyond physical issue. For instance, the UNESCO's Third World Water Report (2009) has emphasized how «alongside the natural forces are the actors who make or influence broad socioeconomic policies that affect water». This report also argues that the cycle of water begins with the interaction of political-process actors - government, civil society and business- deciding on socio-economic development and formulating policy and operational decisions influencing the water circulation in the society (UNESCO-WWAP, 2009).

The next section attempts to show how in the last decade, scholars in geography and environmental science have endeavored to conceptualize, theorize and represent these issues concerning the complex co-evolutionary relationship between water and urban society bringing to light the nature and multiple dimensions of water and the new challenges of governance through the concept of the hydrosocial cycle.

\section{DEVELOPMENT OF THE CONCEPT OF HYDROSOCIAL CYCLE: THE LONG JOURNEY OF WATER FLOWS THROUGH DISCOURSES AND REPRESENTATIONS}

\subsection{The Hydrological cycle}

Since ancient times water, flowing and forming part of humankind and its surrounding environment, has always stimulated in people and civilizations interest and questions about its nature and the way in which it circulates on Earth. It has also become one of the central areas of interest in the discipline of Geography since its foundation (Fonstad, 2013).

Linton $(2008$; 2010) explains how the need to understand the functioning of water for basic human needs and the provision of water supply has offered a variety of observations, explanations, hypotheses, representations and visions from the antiquity to the present. Until the seventeenth century, when the first ideas concerning the circulation of water and its cycle were developed, water was recognized as the «blood of the Earth» and its flow was considered a subterranean, natural, divine, spiritual and theological affair (e.g. Tuan, 1968). The first theories were based on observations of rainfall and river flow in the Seine basin, and on the idea of evaporation from the Mediterranean simulated by Edmond Halley (Goudie, 2000) (Figure 1). 
Figure 1. The subterranean flow of water Athanasius Kircher ca. 1664

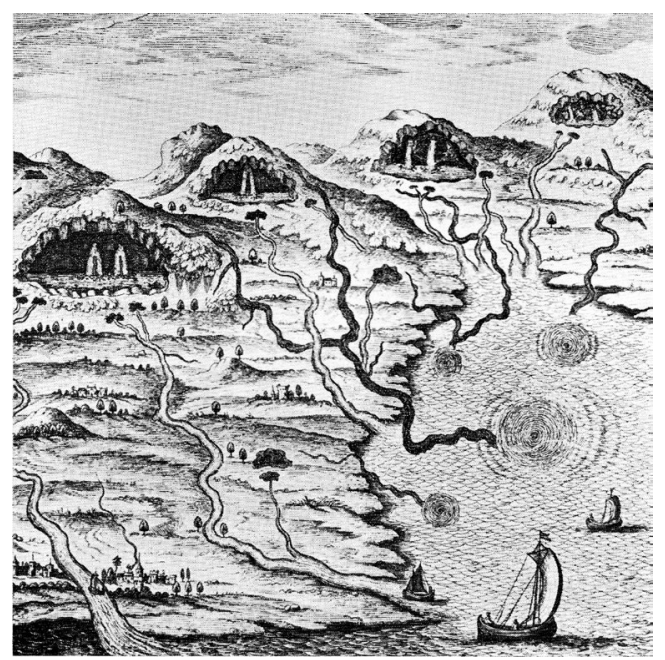

Source: Adams (1938: 437) In Linton (2008)

In time, these ideas and theories have evolved and have brought hydrologists to conceptualize water as a physical substance $\left(\mathrm{H}_{2} \mathrm{O}\right)$, governed by the so-called «hydrological cycle», a concept explaining the «continuous circulation of water through the ocean, land surfaces, water bodies and atmosphere at a variety of geographical scales» (e.g. Jones, 1997), and «fuelled by solar energy, driven by gravity and proceeds endlessly in the presence or absence of human activity.» (Maidment,1993). The development of this term «hydrological cycle» (United States 1931) and the diagrammatic form by which it is typically represented has become the most important concept in the hydrology science by conceptualizing water behaviour in a consistent, uniform and rational manner. In the United States, in the 1930s, it was adapted to the needs of the state planning agencies to sustain the largest program of fluvial transformation ever undertaken, for the purposes of accounting and controlling water flows; promoting the coordination of national resource conservation and development, and for rationalizing and centralizing water planning. Karen Bakker and others have described this way to use the hydrological cycle as a means to guarantee water supply by the State or, in other words, the «state-hydraulic paradigm». As Linton and others have observed, from its conception, the «hydrologic cycle» has produced «scientific» ways of knowing and representing water, but at the same time, it artificially abstracted water from its social, cultural, religious and ecological contexts, reducing it to a single substance $\mathrm{H}_{2} \mathrm{O}$, suitable for technical applications (Figure 2).

Figure 2. The Horton's hydrologic cycle

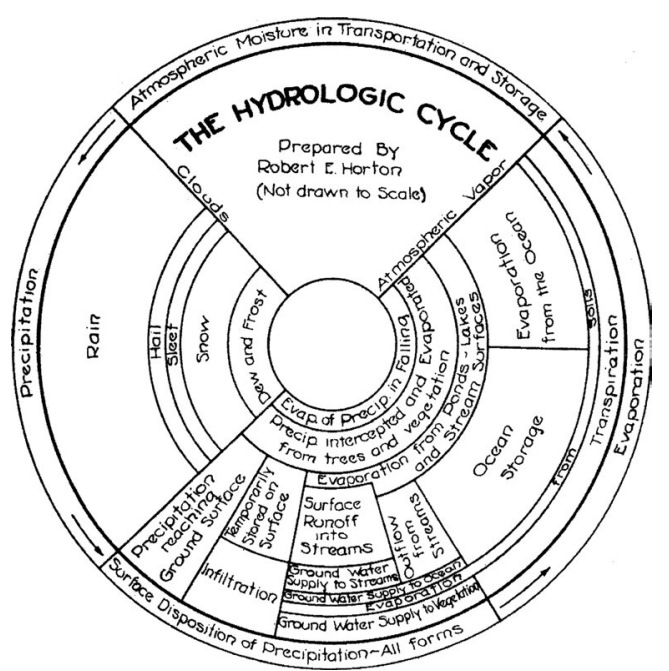

Source: Horton (1931: 193) In Linton (2008) 
This abstraction that Linton (2010) calls «modern water paradigm» helped to underpin the hydrologic cycle discourse with human intervention and development needs. In the Western United States such discourse, justified by the aridity issue, was responsible for from the mid-1930s to the mid1960s, thousands of dams and reservoirs that were built turning and managing every major river by the federal government (Figure 3).

Figure 3. The hydrologic cycle adapted for dams and reservoirs

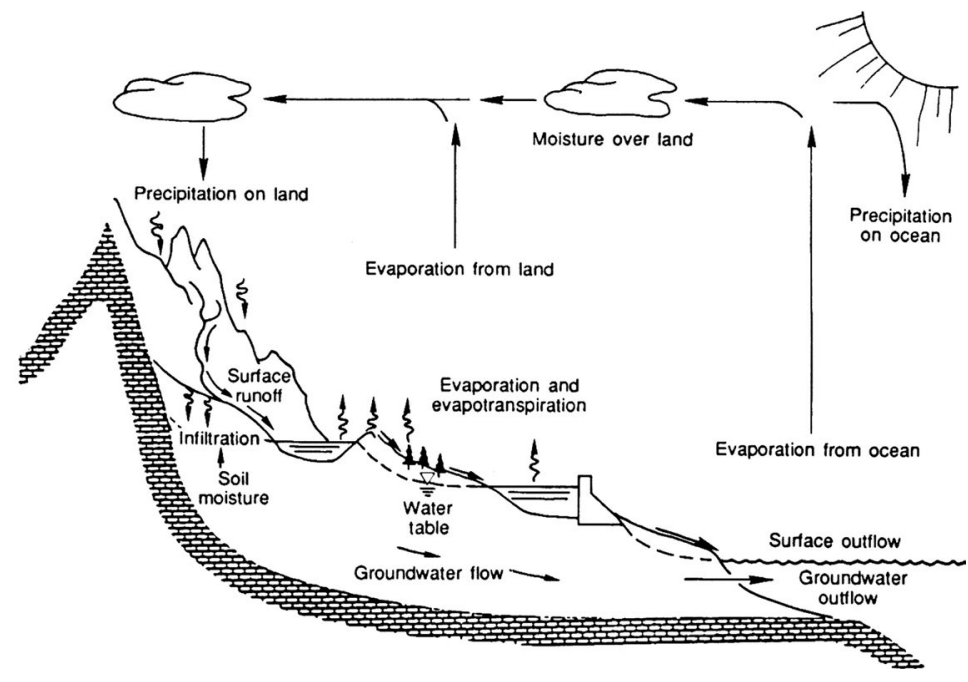

Source: National Research Council $(1991,18)$ In Linton (2008)

The hydrologic cycle started to be used as a tool of control, management and planning of water resources in different ways and for different socio-environmental interests as well as according to specific historical and geographical circumstances (Linton, 2008:630). In this connection, the hydrological framework has been central in many environmental analyses so far, from hydrological water balances (Thornthwaite and Mather, 1955) to the characterization of hazards and risks for humans and waterscapes (White, 1945). Much of these analyses has focused particularly on the hydrological cycle and its influence on climate and global warming (e.g. Ohmura and Wild, 2002; Held and Soden, 2006; Oki and Kanae, 2006; Rind et al., 1992). Mariotti et al. (2002) for example, analyzed the hydrological cycle and its implications for climate variation in the Mediterranean region.

Although hydrologists and physical scientists consider the study of the hydrological cycle fundamental for the knowledge of water flows, many social scientists state that it's cyclical representation establishes a norm at odds with the many different environmental and social contexts regarding social experiences with water (e.g. Linton, 2008).

\subsection{The hydrological cycle in urban environments}

Discussion about the hydrological cycle has increased significantly in the last decades with the development of urban phenomena. It was observed how the hydrologic cycle was becoming more complex in urban areas because of the many anthropogenic influences and interventions (McPherson and Schneider, 1974; Brilly et al., 2006). As a consequence, the resulting «urban» and «hydrological cycle» were then called «urban water cycle» (UWC) (figure 4).

The term «urban water cycle» has been defined as «the natural and managed pathway that water follows in an urban ecosystem, that includes the hydrological cycle and artificial systems to support human life and economic activities, health, hygiene, safety, recreation and amenities» (UNESCO, 2006). In practice, it encompasses the quantification of inputs, consumption and outputs of water flows in an urban region (UNEP-MAP, 2007). Since then, the hydrological cycle framework has incorporated the urban social dimension leading to the development of the science of urban hydrology. Urban water cycle analysis has been, and is still considered particularly important for urban planning (i.e., providing water 
services to growing populations) for identifying problems associated with urbanization (Lee et al., 2010) and for coping with urban water challenges as well as global environmental change (Fletcher, 2013). This concept has put together the interdependence of urban water resources and human activities, and the need for integrated management. In this connection, the concept of total urban water cycle management was introduced in Australia and defined as the collective consideration of the water supply, storm water, waste water and ground water components of urban water service. Components of a total water cycle within urban water management include: (a) re-use of treated waste water, (b) integrated storm water, groundwater, water supply and waste water management, and (c) water conservation approach through reduced water demand and recycling provision (Mitchell, 2006).

\section{Figure 4. The urban water cycle}

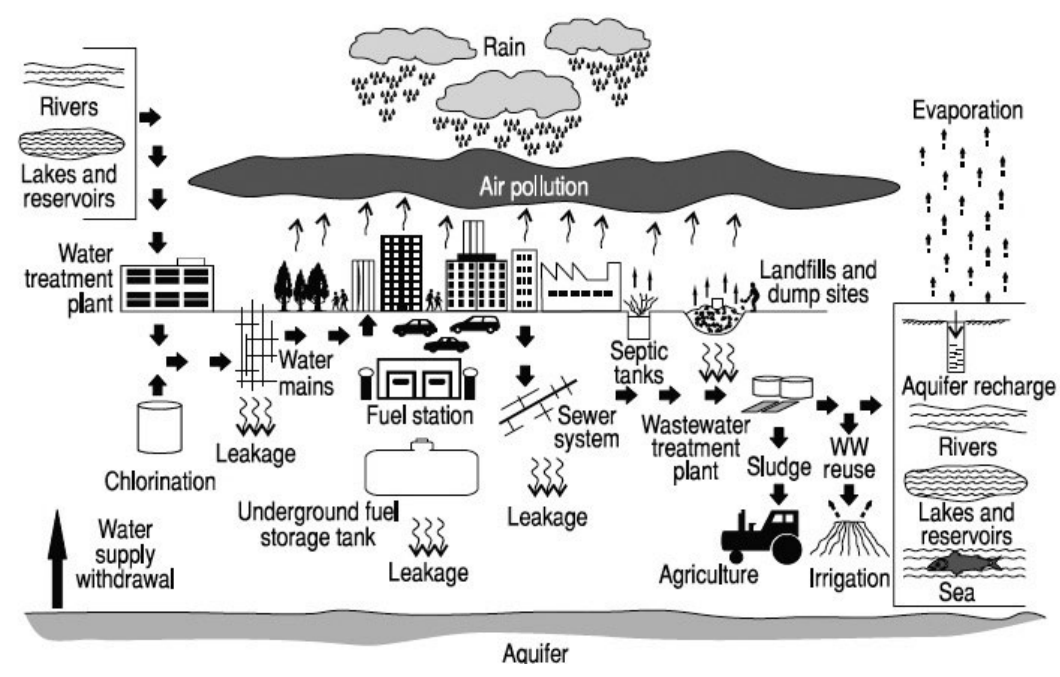

Source: UNESCO-IHP-VI (2006)

\subsection{The integrated urban water cycle}

The understanding of all water flows and balances is essential for an integrated management of urban water. For these reasons the Integrated Management of Urban Water (IWRM) has become an empirical concept which promotes the co-ordinated development and management of water, land and related resources ${ }^{2}$. In this regard, many efforts have been made, some of which have been addressed to the Mediterranean basin. In 1997 the Regional Activity Centre for the Priority Actions Programme of the UNEP's Mediterranean Action Plan acknowledged coastal water resources as a priority issue, because a large part of the basin was already experiencing water scarcity due to the rapid population growth, urbanization processes and mass tourism. In the attempt «to support an integrated approach to water resources planning and management» the hydrologic cycle representation was adapted to the Mediterranean coastal cities (Figure 5) «to integrate the relevant knowledge in the physical and social sciences and to create a theoretical and practical basis» (PAP/RAC, 1997).

Despite this attempt, water problems have become more persistent due to a scant attention of the land, sea, river basin and coastal zones interface in the context of resource management. Additionally, as international and European institutions, agencies and several programs, activities and directives such as the European Water Framework Directive (2000) covered only distinct parts and issues important to the urban water cycle, new guidelines have been provided to address this gap through the integrated framework called Integrated Urban Water System Management in a Coastal Area (IWSMCA) to promote

2 The IWRM is a concept widely accepted and defined by the Global Water Partnership. Initially, many parts of the concept were identified during the first global water conference in Mar del Plata in 1977. After Agenda 21 and the World Summit on Sustainable Development in 1992 in Rio the concept was extended in practice. 
the coordinated planning, development and management of water, land and related physical and human resources in coastal urban areas (UNEP-MAP, 2007). This framework considers, besides water flows pertinent to towns and cities along the Mediterranean coast (UNEP-MAP, 2007:19) the interactions with factors such as culture; social groups and power relations; history; perceptions and ideologies; political organization; urban form; economic structure and development. These guidelines intended for engineers, urban water resource managers, urban planners, and expanded to social scientists, provided a new representation of integrated water flows in coastal urban systems (UNEP-MAP, 2007:4). A similar representation of the flows of water for the city of Barcelona was provided by Barracó et al. in 1999. It included supplementary sources of water: bottled water and water-containing foods, considered of particular importance in urban areas especially in coastal tourist cities (UNESCO, 2006:30).

Figure 5. Schematic presentation of the integrated development, management and use of coastal water resources (Margeta, 1994)

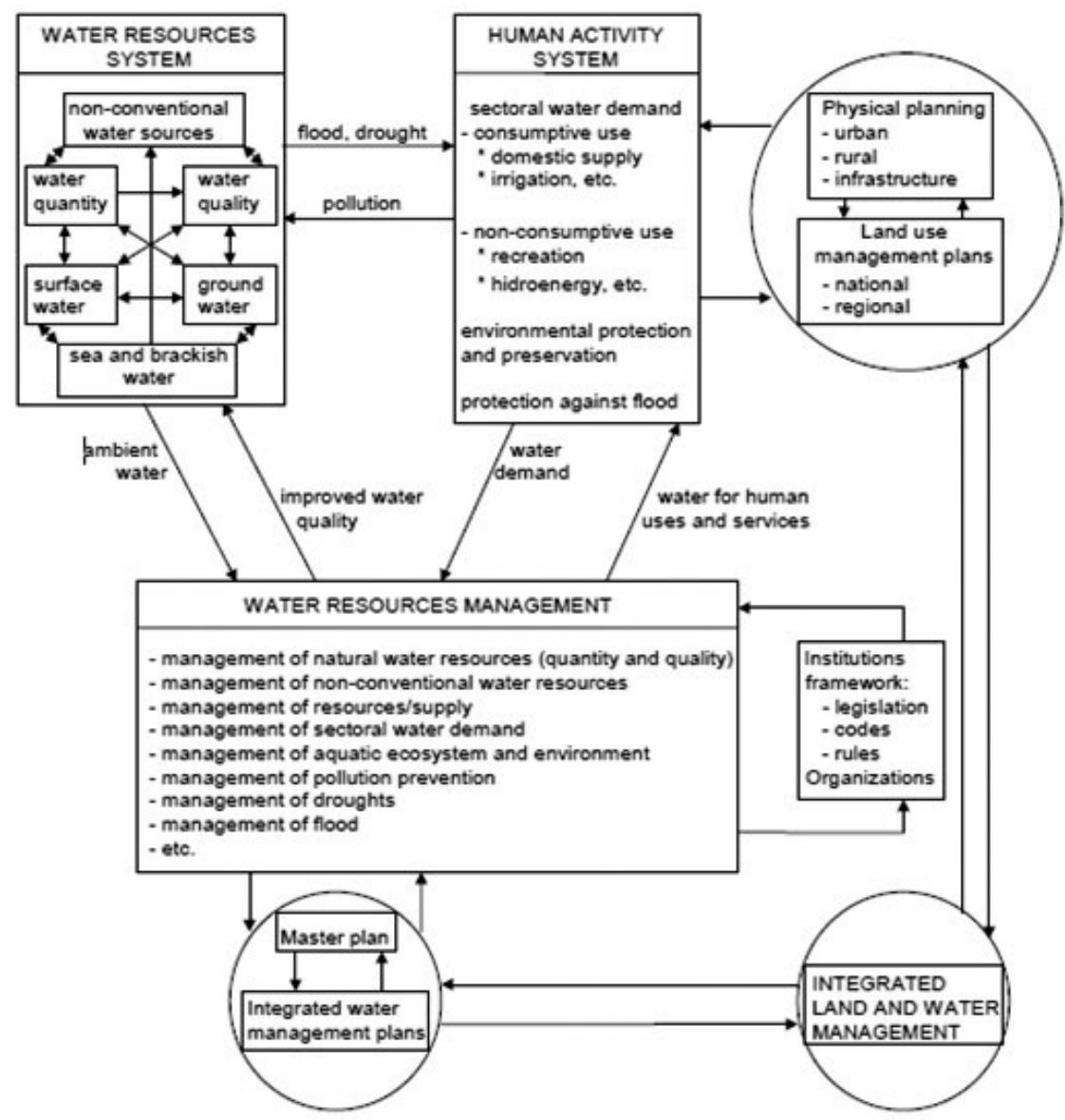

Source: UNESCO-IHP-VI (2006)

In attempting to investigate and integrate all physical water flows in urban areas and coastal areas to be safely used, reused and returned to nature through their management, the urban water cycle (see figure 6 conceptualized by Vörösmarty et al. (2004) has provided important methodological and empirical advances so far.

The use of hydrological models, quantitative assessments (e.g. in the Mediterranean, Amores et al., 2013), and indicators to assess the sustainability of urban water cycle (Van Leeuwen et al., 2011) has then been set up and retained «essential for understanding changes in the water cycle as a result of urbanization and for the recovery of a comprehensive water cycle system in urban areas». In particular, the models have been developed and applied to demonstrate their functionality in estimating and/or forecasting the water demand in urban areas worldwide. Such models and cities include the Aquacycle model in Canber- 
ra, Australia (Mitchell et al., 2001) and in Seoul (Lee et al., 2010), the City Water Balance (CWB) model (Last and Mackay, 2010), the Life Cycle Assessment (LCA) methodology in Alexandria, Egypt (Mahgoub, 2010), as well as the Urban Water Optioneering Tool (UWOT) (Makropoulos et al., 2008). The Alexandria's study, for example, focused on the assessment of the urban water system and provided scenarios encompassing technical interventions, better management procedures, and generally, new solutions for improving the systems in the future.

Figure 6. The global physical and social water system.

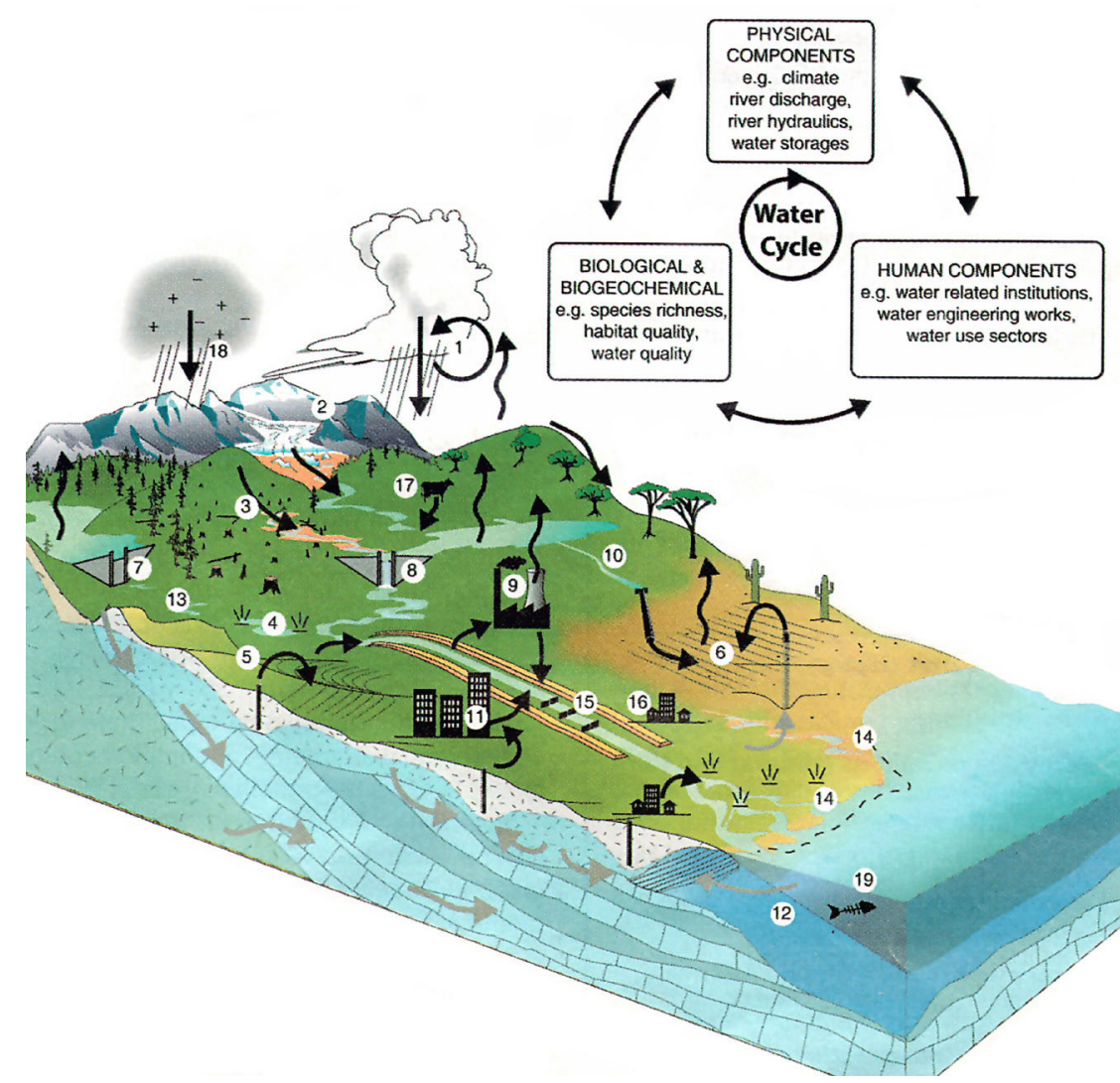

Source:Vörösmarty et al. (2004:509).

\subsection{The integrated urban water cycle and its metabolism}

In pursuing the objective of providing detailed information and expanding knowledge on water flows in the city, models of the hydrological cycle continue to evolve. Rozos and Makropoulos (2013), for example, have recently argued that the models mentioned previously that include the distribution system, the consumption and the drainage of wastewater and storm water consider only a part of the urban water cycle. For a complete study of the urban water cycle, they have redesigned the UWOT model as an urban metabolism model «to provide a common modelling environment for the whole urban water cycle from source to tap and back» (Rozos and Makropoulos, 2013:140). According to these authors this holistic approach applied to the case of Athens, Greece, and integrates the basic rationale behind the urban metabolism concept, which suggests that the relationship between the environment and an urban system can be described by systematically recording all flows to and from the environment (Minx et al., 2010). In this direction, a new model able to analyze every flow related to the urban metabolism is now being developed by the EU project TRansitions to the Urban Water Services of Tomorrow - TRUST (TRUST, 2013). The latter is done by taking into account the economic, social and environmental conditions as well as local circumstances and existing systems (natural, engineered, and socio-political) of urban water governance. 
The concept of urban metabolism, first developed by Abel Wolman (1965) in response to the rapid urban expansion and deterioration of air and water quality in American cities, is still recognized as an important means to achieve sustainable urban development (Kennedy et al., 2007). In practice, it involves the quantification of the inputs, outputs and storage of energy, water, nutrients, materials and wastes for an urban region (Kennedy et al., 2011). Among all these components water is considered the largest and closely linked with other components such as energy (Kennedy et al., 2007). Kennedy, et al. (2011) has charted out a history of urban metabolism studies, including urban water issues and has maintained that such studies have practical applications to urban designers and planners as an adaptive approach to technological and socio-political solutions and their consequences (figure 7).

Figure 7. Water cycle into urban metabolism of Brussels, Belgium (1970s)

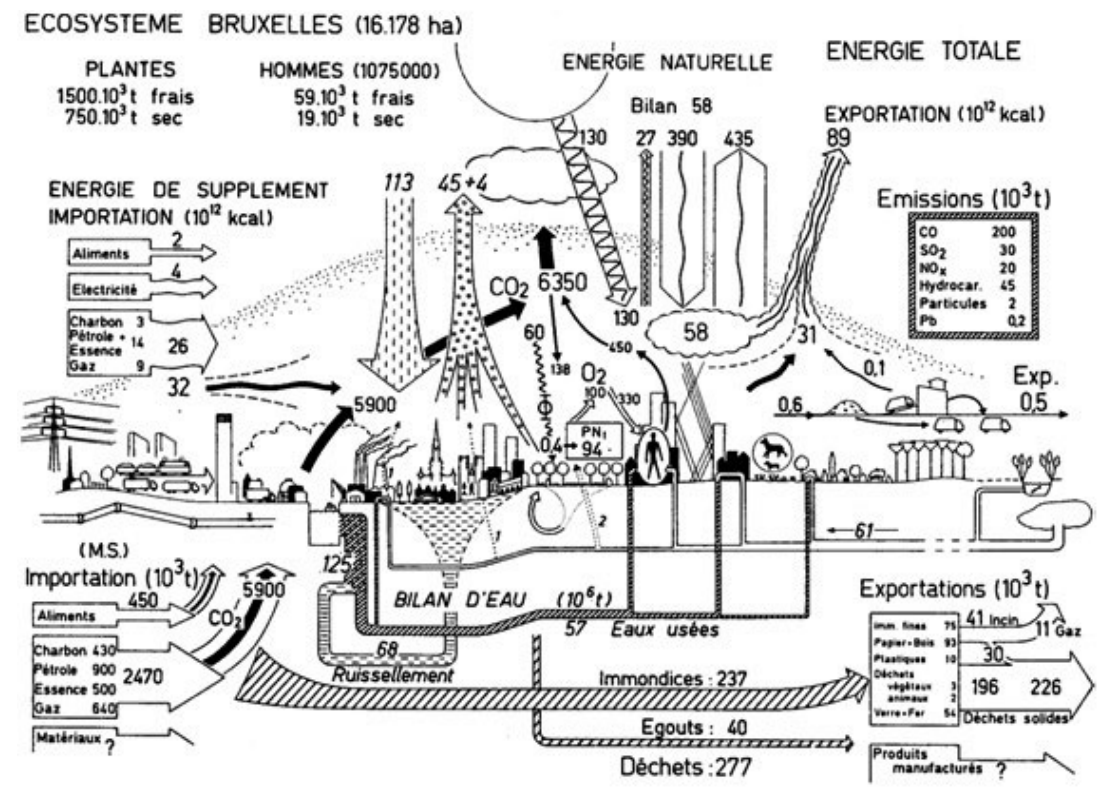

Source: Duvigneaud and Denaeyer-De Smet (1977)

The concept of urban metabolism has been particularly employed by the new discipline of Urban Ecology discipline. From this perspective cities are seen as ecosystems embedded in a larger system. According to Grimm et al. (2000) the city studied as an ecosystem allows for the analysis of flows of energy, materials and information together with the interactions between human and non-human elements of the system so that the complexity of urban systems can be fully captured and interpreted (Grimm et al. 2000; Mehmood, 2010; Newman, 1999). Scholars in this field focus not just on understanding the ecology of cities but on problem identification in the functioning of urban systems in order to develop and address urban planning, policy and design interventions. Alberti and others (1999; 2008) have shown how urban ecosystems consist of multiple interlinked subsystems that continually interact among each other in which humans and their activities, rather than being external, become incorporated into these ecosystems (Alberti, 1999; Grimm et al., 2000).

According to Rapoport (2011), in recent years the concept of urban metabolism has been employed in a diverse range of disciplines thus expanding our knowledge about resource use in urban areas and increasing our understanding of the relationship between urban economies and the environment and, as it will be shown next, providing a critical perspective about the way in which the urban is produced by the relations between social and natural processes.

\subsection{The hydrosocial cycle}

Hydrological sciences have made great advances in providing knowledge, techniques, system modeling technology, as well as numerous international and national efforts in global and regional water re- 
sources assessments and applications. In particular, over the past ten years, these advances have included a growing awareness of the ecological and social implications of «water management».

However, as increasing types of water flows have become ever more powerfully interdependent with the growth of world population and its economic activities of production and consumption, these views have fallen under scrutiny from social scientists. Intellectual, political, economic and social factors have given rise to new ways of understanding the nature of water (Linton, 2010). Contemporary complexity of water in urban spaces has gained the attention of many scholars in particular from the geography and social science disciplines. On the one hand, they have raised questions attempting to address the problem of water in environment and urban systems. They wonder not just how much water there is and for what, but who has access? Who controls and manages it? What are the power relations in the society through which this water circulates? How do water flows influence the urbanization process and, in turn, are influenced by urbanization? (Swingedown)

On the other hand, they have put forward the «hydrosocial cycle» concept, which incorporates newer approaches drawn from water political ecology and social studies of science (Budds, 2008, 2009; Kaika, 2005; Linton, 2008, 2010; Swyngedouw, 2004).

The political ecology of water explicitly considers how the relations among political, social, economic and power action, force and dimension influence current, or give place to new, water flows becoming socials. This perspective has attempted to analyze how the flow of water may influence the urban space and how this resource is embedded in the social dimension of the city. Therefore, the complex relationship between water and society has been conceptualized with the emerging «hydrosocial cycle» concept. In particular the concept has been developed by geographers working in the tradition of the political economy and political ecology of water (see e.g. Boelens, 2013; Barnes, 2012; Wang, Otto, and $\mathrm{Yu}, 2013 ;$ Gandy, 2008). For the last 15 years, the hydrosocial cycle concept has attracted significant attention in the context of contemporary debates about nature-social interactions and among critical geographers. From the political ecology perspective the hydrosocial cycle helps to disclose how flows of water are produced by, and acting on dynamic social, political and economic power relations at various nested and articulated geographical scales, also among actors and institutions (Cook and Swyngedouw, 2012). It encloses water's symbolic and material dimensions (Linton, 2008) and has been used to reveal capital accumulation and inequalities of access to water induced by water management practices as well as the processes of water commodification and its social effects (Cook and Swyngedouw, 2012).

During the last decades the political ecology discipline has been appropriately extended to the foreground of «urban» through «Urban Political Ecology» (UPE). According UPE scholars, it provides an integrated and relational approach that helps untangle the interconnected economic, political, social and ecological processes that together go to form and shape urban landscapes. Many studies drawn on this approach have explored how nature and city can be viewed as a process of socio-physical metabolism under the current capitalism, and infused by relations of power in which social actors, institutions and scales play a fundamental role (e.g. local, regional, global). Through the notion of metabolism UPE scholars have moved away from a society-nature dualism to seeing the city as a process of metabolically transformed nature, even a socio-natural hybrid or a cyborg of machine and organism (Kaika $\&$ Swyngedouw 2000, Gandy 2005).

Studies on urban political ecology have particularly focused on water resources. A relevant contribution was provided by Erik Swyngedouw (1997) with "Power, Nature and the City. The Conquest of Water and The Political Ecology of Urbanization in Guayaquil, Ecuador: 1880-1980". With this study Swyngedoyw reconstructed both theoretically and empirically, the political conditions, social and economic and power relations that lead to the current water flows, both physical and social, in the city of Guayaquil (Ecuador). This contribution has become an important reference in the field of Urban political ecology and continues to many recent emerging studies, also providing new discoursers and representations of water flows in urban areas and social environments (figure 8 and 9). 
Figure 8. The Postmodern Hydrologic Cycle

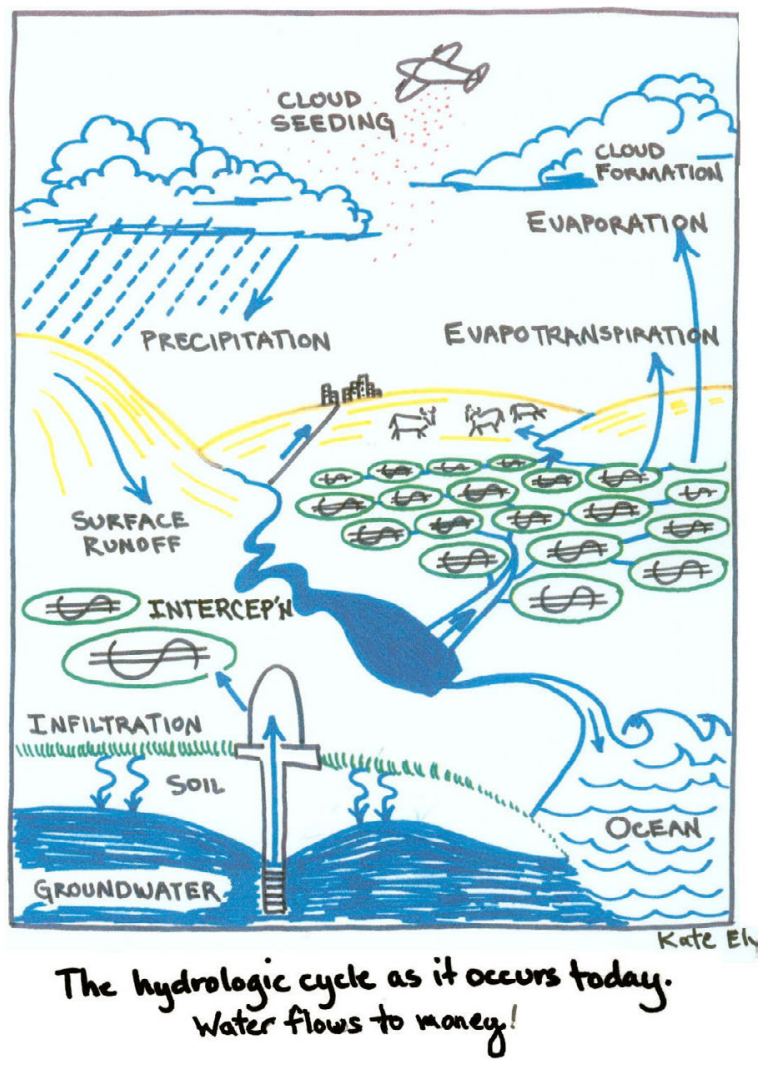

Source: Kate Ely (2008) and worldview.
Figure 9. The Andean hydrocosmological cycle

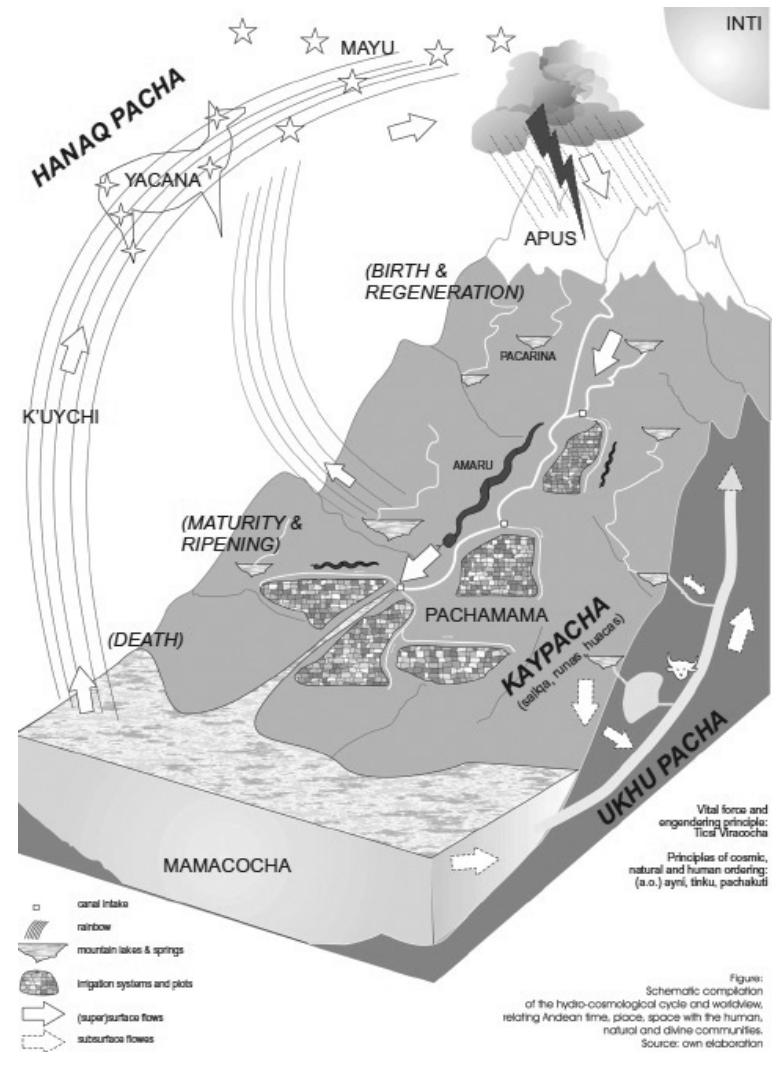

Source: Boelens (2013)

The next section provides a review of works elaborated on the base of these concepts (see table 1).

\subsection{Chronological review of hydrosocial cycle studies}

This review shows how many studies have emerged on the basis of political ecology and urban political ecology perspective, focusing on hydrosocial flows, opening new perspectives to understand different urban water governance models through the hydrosocial concept.

Table 1. Cronological review of hydrosocial cycle studies

\begin{tabular}{|c|c|c|c|c|}
\hline Author/s (year) & City/Region of study & Thematic focus & $\begin{array}{c}\text { Disciplinary } \\
\text { Approach }\end{array}$ & Methodology \\
\hline $\begin{array}{c}\text { Swyngedouw } \\
(\mathbf{1 9 9 7 ; 2 0 0 4 )}\end{array}$ & Guayaquil - Ecuador & $\begin{array}{c}\text { Urbanization; water scarcity; water circulation; } \\
\text { power; political-economic transformations }\end{array}$ & $\begin{array}{c}\text { Urban political } \\
\text { ecology }\end{array}$ & $\begin{array}{c}\text { Historical } \\
\text { analysis }\end{array}$ \\
\hline Kaika (2006) & Athens (Greece) & $\begin{array}{c}\text { Urbanization; water scarcity; metabolism; } \\
\text { water circulation; power; political-economic } \\
\text { transformations }\end{array}$ & $\begin{array}{c}\text { Political } \\
\text { Ecology } \\
\text { analysis; } \\
\text { Political } \\
\text { ecology } \\
\text { concepts }\end{array}$ \\
\hline Fleury (2003) & $\begin{array}{c}\text { Montreal Metropolitan } \\
\text { Region (Canada) }\end{array}$ & $\begin{array}{c}\text { Water supply and management; urban } \\
\text { governance }\end{array}$ & $\begin{array}{c}\text { Political } \\
\text { ecology }\end{array}$ & $\begin{array}{c}\text { Historical } \\
\text { analysis }\end{array}$ \\
\hline Castro (2004) & Mexico Metropolitan Area & $\begin{array}{c}\text { Social struggles over the access to and } \\
\text { improvement of water services }\end{array}$ & $\begin{array}{c}\text { Political } \\
\text { Ecology }\end{array}$ & $\begin{array}{c}\text { Political } \\
\text { Ecology } \\
\text { concepts }\end{array}$ \\
\hline Bakker (2005) & England and Wales & $\begin{array}{c}\text { Commodification initiatives in England and } \\
\text { Wales; water crises; reregulation of the water } \\
\text { supply industry and drinking water quality }\end{array}$ & $\begin{array}{c}\text { Geography; } \\
\text { Political } \\
\text { ecology }\end{array}$ & $\begin{array}{c}\text { Political } \\
\text { Ecology } \\
\text { concepts }\end{array}$ \\
\hline
\end{tabular}




\begin{tabular}{|c|c|c|c|c|}
\hline Loftus (2006) & $\begin{array}{l}\text { Durban's waterscape } \\
\text { (South Africa) }\end{array}$ & Water supply & $\begin{array}{l}\text { Urban political } \\
\text { ecology }\end{array}$ & $\begin{array}{c}\text { Spatial- } \\
\text { temporal } \\
\text { dynamics } \\
\text { of capital } \\
\text { accumulation }\end{array}$ \\
\hline Gandy (2008) & $\begin{array}{l}\text { Mumbai Metropolitan } \\
\text { region (India) }\end{array}$ & $\begin{array}{l}\text { Social inequalities within the postcolonial } \\
\text { metropolis. Water and sanitation crisis; } \\
\text { capitalist urbanization }\end{array}$ & $\begin{array}{l}\text { Political } \\
\text { Ecology }\end{array}$ & $\begin{array}{l}\text { Political } \\
\text { ecology } \\
\text { concepts }\end{array}$ \\
\hline Budds (2009) & $\begin{array}{l}\text { La Ligua river basin } \\
\text { (Chile) }\end{array}$ & Water resources; Policy; Technocracy & $\begin{array}{l}\text { Political } \\
\text { ecology } \\
\text { Groundwater } \\
\text { Science }\end{array}$ & $\begin{array}{l}\text { Hydrology } \\
\text { Modelling } \\
\text { Policy }\end{array}$ \\
\hline Bardati (2009) & $\begin{array}{c}\text { St. Francis River } \\
\text { Watershed (Canada) }\end{array}$ & $\begin{array}{c}\text { Exploration of the socio-physical dualism } \\
\text { inherent in a specific watershed planning } \\
\text { process in response to the Quebec Water Policy } \\
\text { (2002) }\end{array}$ & $\begin{array}{l}\text { Political } \\
\text { ecology }\end{array}$ & $\begin{array}{l}\text { Political } \\
\text { ecology } \\
\text { concepts }\end{array}$ \\
\hline Kallis (2010) & Athens Metropolitan area & $\begin{array}{l}\text { Urbanization; water scarcity; water circulation; } \\
\text { power; political-economic transformations }\end{array}$ & $\begin{array}{l}\text { Urban political } \\
\text { ecology }\end{array}$ & $\begin{array}{l}\text { Historical } \\
\text { analysis }\end{array}$ \\
\hline Zimmerer (2011) & $\begin{array}{c}\text { Calicanto area } \\
\text { (Cochabamba, Bolivia) }\end{array}$ & $\begin{array}{c}\text { Landscape technology; Irrigation; } \\
\text { Development; Landscape; Water resources } \\
\text { Agrobiodiversity }\end{array}$ & $\begin{array}{c}\text { Resilience } \\
\text { ecology, } \\
\text { political } \\
\text { ecology, and } \\
\text { actor-network } \\
\text { theory }\end{array}$ & $\begin{array}{l}\text { Political } \\
\text { ecology and } \\
\text { actor-network } \\
\text { theory concepts }\end{array}$ \\
\hline Barnes (2012) & Egypt & $\begin{array}{c}\text { Drainage water reuse; Agriculture Irrigation } \\
\text { Hydrosocial cycle; Non-conventional source } \\
\text { Egypt }\end{array}$ & $\begin{array}{l}\text { Hydrosocial } \\
\text { cycle } \\
\text { framework }\end{array}$ & $\begin{array}{l}\text { Hydrosocial } \\
\text { concepts }\end{array}$ \\
\hline $\begin{array}{l}\text { Budds and Hinojosa } \\
\qquad(2012)\end{array}$ & Peru & $\begin{array}{l}\text { Waterscape; Resource extraction; } \\
\text { Hydrosocial Governance }\end{array}$ & $\begin{array}{l}\text { Political } \\
\text { ecology }\end{array}$ & $\begin{array}{l}\text { Politics of } \\
\text { scale in water } \\
\text { governance }\end{array}$ \\
\hline Clarke-Sather (2012) & $\begin{array}{l}\text { Semi-arid Zuli river valley } \\
\text { in (China) }\end{array}$ & $\begin{array}{l}\text { Food-water relationship; Hydrosocial } \\
\text { Governance }\end{array}$ & $\begin{array}{l}\text { Political } \\
\text { ecology }\end{array}$ & $\begin{array}{l}\text { Politics of } \\
\text { scale in water } \\
\text { governance }\end{array}$ \\
\hline Norman (2012) & $\begin{array}{l}\text { Salish sea, Pacific } \\
\text { Northwest, (Canada, US) }\end{array}$ & $\begin{array}{l}\text { Transboundary water governance for } \\
\text { indigenous communities }\end{array}$ & $\begin{array}{l}\text { Political } \\
\text { ecology }\end{array}$ & $\begin{array}{l}\text { Politics of } \\
\text { scale in water } \\
\text { governance }\end{array}$ \\
\hline Perramond (2012) & New Mexico (US) & Water rights; Adjudication process & $\begin{array}{l}\text { Political } \\
\text { ecology }\end{array}$ & $\begin{array}{l}\text { Politics of } \\
\text { scale in water } \\
\text { governance }\end{array}$ \\
\hline Vogel (2012) & $\begin{array}{l}\text { Columbia river basin } \\
\text { (Canada, US })\end{array}$ & $\begin{array}{l}\text { Historical environmental analysis of the } \\
\text { management of the Columbia river basin to } \\
\text { critique watershed and river basin management }\end{array}$ & $\begin{array}{l}\text { Political } \\
\text { ecology }\end{array}$ & $\begin{array}{l}\text { Politics of } \\
\text { scale in water } \\
\text { governance }\end{array}$ \\
\hline Wang (2013) & $\begin{array}{l}\text { Zhuolu County, Guanting } \\
\text { Watershed (China) }\end{array}$ & $\begin{array}{l}\text { Village-level irrigation management in water } \\
\text { scarce northern China }\end{array}$ & $\begin{array}{l}\text { Political } \\
\text { Ecology }\end{array}$ & $\begin{array}{l}\text { Institutional } \\
\text { framework }\end{array}$ \\
\hline $\begin{array}{l}\text { Larrabeiti Rodríguez } \\
\qquad(2013)\end{array}$ & Alicant (Spain) & $\begin{array}{l}\text { Hydrosocial cycle and urbanization; water } \\
\text { scarcity; Metabolism }\end{array}$ & $\begin{array}{c}\text { Urban Political } \\
\text { Ecology; } \\
\text { Political } \\
\text { economy }\end{array}$ & UPE concepts \\
\hline Mollinga (2013) & $\begin{array}{l}\text { Tungabhadra Left Bank } \\
\text { Canal, (India) }\end{array}$ & $\begin{array}{l}\text { How human agency transform hybrid and } \\
\text { multi-scale water control system }\end{array}$ & $\begin{array}{l}\text { Geography } \\
\text { of the } \\
\text { hydrological } \\
\text { cycle }\end{array}$ & $\begin{array}{l}\text { Hydrological } \\
\text { cycle concepts }\end{array}$ \\
\hline Banister (2013) & $\begin{array}{l}\text { northwest Mexico's } \\
\text { RíoMayo Valley }\end{array}$ & $\begin{array}{l}\text { Account of irrigation politics, the flows of } \\
\text { matter, and nonlinear dynamics in northwest } \\
\text { Mexico's Río Mayo Valley }\end{array}$ & $\begin{array}{l}\text { Political } \\
\text { geography; } \\
\text { Ontology } \\
\text { of flow } \\
\text { Geophilosop. }\end{array}$ & $\begin{array}{l}\text { Political } \\
\text { ecology } \\
\text { concepts }\end{array}$ \\
\hline Boelens (2013) & Mollepata (Peru) & $\begin{array}{l}\text { Socionatures; Water management; Cultural } \\
\text { politics; Cosmology }\end{array}$ & $\begin{array}{l}\text { Political } \\
\text { Ecology; } \\
\text { hydrosocial } \\
\text { cycle }\end{array}$ & $\begin{array}{l}\text { hydrosocial } \\
\text { cycle } \\
\text { analysis }\end{array}$ \\
\hline
\end{tabular}




\begin{tabular}{|c|c|c|c|c|}
\hline Bury (2013) & $\begin{array}{l}\text { Santa River Watershed } \\
\text { (Peru) }\end{array}$ & $\begin{array}{l}\text { How ecological change and societal forces } \\
\text { shape the future of water resources and water } \\
\text { governance in the region }\end{array}$ & $\begin{array}{l}\text { Political } \\
\text { Ecology }\end{array}$ & $\begin{array}{l}\text { Coupled } \\
\text { historical } \\
\text { analysis }\end{array}$ \\
\hline Bouleau (2013) & $\begin{array}{c}\text { Rhône and the Seine river } \\
\text { basin (France) }\end{array}$ & $\begin{array}{l}\text { Hydrosocial cycle to account for the way in } \\
\text { which the course of water and that of human } \\
\text { affairs were intertwined in the Rhône and the } \\
\text { Seine river basins }\end{array}$ & $\begin{array}{l}\text { Political } \\
\text { ecology; Social } \\
\text { studies of } \\
\text { science }\end{array}$ & $\begin{array}{l}\text { Political } \\
\text { ecology } \\
\text { concepts }\end{array}$ \\
\hline $\begin{array}{l}\text { Bourblanc \& } \\
\text { Blanchon (2013) }\end{array}$ & $\begin{array}{l}\text { Catchment areas (South } \\
\text { Africa) }\end{array}$ & $\begin{array}{c}\text { Construction of interbasin transfers; } \\
\text { power struggles }\end{array}$ & $\begin{array}{l}\text { Geography } \\
\text { and political } \\
\text { science }\end{array}$ & $\begin{array}{l}\text { Hydrosocial } \\
\text { cycle as } \\
\text { framework; } \\
\text { Institution } \\
\text { analysis }\end{array}$ \\
\hline Fernandez (2013) & $\begin{array}{l}\text { Garonne watershed } \\
\text { (Southwestern France) }\end{array}$ & $\begin{array}{c}\text { How technologies } \\
\text { of government, practices, devices and } \\
\text { discursive regimes contribute to shape } \\
\text { specific hydrosocial cycles; water scarsity }\end{array}$ & $\begin{array}{l}\text { Political } \\
\text { Ecology }\end{array}$ & $\begin{array}{l}\text { Historical } \\
\text { Analysis; Actor } \\
\text { analysis }\end{array}$ \\
\hline
\end{tabular}

Source: Own elaboration.

\section{EXTENDING THE URBAN HYDRO-SOCIAL CYCLE FRAMEWORK TO TOURIST COASTAL CITIES}

\subsection{Mediterranean basin as laboratory of analysis}

The Mediterranean basin is considered by many scholars an interesting laboratory for exploring current processes of socio-environmental change (see e.g. Gössling and Hall, 2006; Carraro, 2009)for, among other reasons, centuries of transformations creating a very complex socio-environmental mosaic. Natural resources needed for settlement, first among all water, have influenced most human-induced changes in the basin. The evolution of this landscape has been governed by major interaction of water flowing across the land with human social actions (Bratina-Jurkovi, 2011; Barton et al., 2010). Coastal areas are the space where this interaction has taken place and where water also represents the most vulnerable resource. This laboratory may, therefore, be particularly interesting for exploring how these interactions continue to shape the hydrosocial cycles in coastal cities.

The Mediterranean is generally identified as a unique entity, where physical, cultural and social processes are rich, complex and uniform. However, Violi and Lorusso (2011) point out that as soon as we start investigating this supposed unity, it breaks down into a thousand different entities, images and local realities recognizable from the outside, but also extremely differentiated from the inside.

Indeed the basin is a space that contains substantial differences. The Western Mediterranean is the most urbanized area and is characterized by the strong development of tourism (Unep/Map, 2012). While over a half of the world population is considered urbanized, in the Mediterranean countries, two out of three inhabitants already live in urban areas mostly located near the coasts (UNEP/MAP, 2012) and expected to grow significantly by 2025 (UN/MAP/BP/RAC, 2009). Rising demand of water is the result of growing urban populations and visitors to tourist destinations. Tourism is a vital economic activity for many of these countries. 12 percent of the Spanish GDP, for instance, is generated by tourist related activities. Drawing upon their geographical location and characteristics, Mediterranean destinations are by far the largest global tourism destinations, attracting almost a third of the world's international tourists, and generating more than a quarter of international tourism receipts (UNWTO, 2012). In parallel, the compact traditional form, typical of the many Mediterranean cities, has experienced profound transformations resulting in more dispersed form. This so-called «urban sprawl» phenomenon has become a very a remarkable characteristic of urban development in North America and then in Europe, and it is now expanding in the Mediterranean. Initially, it was caused mainly by changes in socioeconomic and political systems, and the incapacity of planning in the South to control urban expansion (Gaspar, 1984; Munoz, 2003). Urban sprawl and scattered development in the vicinity of urban hubs are still today encouraged by current socio-economic change processes and especially by the growth in the socalled residential tourism. In particular, sprawl raises concern about its potential negative and irreversible 
effects for urban sustainability (PB/CAR, 2003; European Commission Joint Research Centre, 2002; EEA, 2006). Studies have demonstrated that dispersed forms generally produce wider environmental impacts than compact urban forms, including land and fresh water (Rico-Amoros et al., 2009). Further, in rapidly developing urban areas water system infrastructures may suffer losses in the distribution network, often exceeding 30 percent of the distribution input (UNEP-MAP, 2007).

Tourism has also facilitated the process of urbanization and urban sprawl. Some authors explain how tourism urbanization has produced a particular urban form in the Mediterranean (Gössling and Hall, 2006) with the increase in comfort requirements and the development of facilities to diversify leisure activities (swimming pools, golf courses, etc.). Therefore tourist activity takes the traits of a true «regional brand» influencing and being influenced by the global scale (Ashworth and Page, 2011).

In the Mediterranean basin, water consumption from tourism is relatively low compared to other sectors such as agriculture. However, according to existing estimates (WTM, 2007, Blue Plan, 2008) water for tourism is a critical resource that is expected to experience the largest increases in demand by 2025. As observed (see e.g. Rico-Amoros et al., 2009; Hofa and Schmitt, 2011) water availability, demand and consumption vary according to the type of urban and tourist settlement, and the water requirements of future expansions will probably depend on these forms strategically chosen for development (Kent et al., 2002) which are also likely to increase and intensify the hydrosocial flows. Seasonality is a particular feature of tourism in Mediterranean coastal areas, intensifying water problems such as shortages and conflicts of use with other sectors during the summer months.

Moreover, global climate predictions point at an increase of aridity conditions in the Mediterranean areas as well as sea level rise in the Eastern Mediterranean. These trends may affect direct physical water availability requiring substantial changes in the sources of supply. In Spain desalination plants have often been often chosen as a solution to produce and ensure fresh water, but this and other solutions such as dams or transfers also have important environmental impacts (UNEP-MAP, 2007).

Finally, but most importantly, decisions, management, power and social control of flows of water, as well as different water governance models, for example private or public, may substantially influence or be influenced by, the urban hydrosocial cycles. Hydrosocial cycles will vary therefore according to whether urban water flows are controlled by public or by private interests and the history and recent changes in this control.

Therefore, as anticipated earlier, different configurations may emerge according to the considered context. In this regard, the heritage town of Venice and the mass tourism resort of Benidorm differ profoundly from many other coastal cities of the Mediterranean region. Their unique urban evolution and their relations with water flows characterize today these two cities as paradigmatic examples of coastal tourist models.

\subsubsection{Venice}

The historic city of Venice, in the Veneto Region of Northeast Italy, is considered one of the most important tourist destinations worldwide with a flow of about 22 million tourists per year. Today the current urban model of the city is characterized by historical urban parts coexisting with other parts constructed and transformed more recently for tourist purposes. Venice spreads over 118 tiny islands that were consolidated and organized in a unique urban system characterized by canals, and a network of small streams that are the veritable arteries of this city. Venice is therefore the result of a dynamic process of interaction between people and water within a particular and complex natural ecosystem. The spectacular evolution of this city draws on secular people's struggle against a hostile nature and the continuous power and social control exerted over the management and the governance of land and water resources, including the lagoon. Today, tourism represents the major challenge for the city in physical and social terms.

Although population growth is a phenomenon occurring in many cities today, over the last fifty years, Venice has experienced a continued population loss and now stands at less than 60000 inhabitants. This process has been mainly attributed to tourism. 
In the last decade the high tourism pressure on the city of Venice has resulted in a partial functional transformation. Therefore, the city has continued to grow in the mainland producing an uncontrolled process of urban sprawl in the nearby Veneto region. These current social and environmental processes of change are influencing the flows of water of this city of which the provision for tourists is the main component.

The model of water governance in Venice is public and water supply coverage attains 100 percent of the city. However, wastewater treatment (sewage) coverage is only 70 percent. Thus part of the sewage in the city remains untreated and flows directly into the Venice Lagoon, which receives an organic and pathogen loading equivalent to more than 400000 people during the tourist season. The city is also affected by extreme flooding caused by climatic events with short-term implications (including the reduction of tourism-related income) and long-term implications (notably damage to the city's building fabric and architectural heritage).

Water is today a critical resource for Venice. It is fairly abundant but water quality (resources and drinking water) is an ongoing challenge. Additionally, more water resources will be needed to sustain this economic sector which is vital for the city.

\subsubsection{Benidorm}

Benidorm, located in the Eastern Spain, is a typical example of the mass tourism resorts that emerged along the Mediterranean coast in the 1960s and has become one of the most famous holiday destinations in Europe. Its urban form is characterized by concentrated tourist settlements with very high densities and vertical growth as a result of a profound process of urbanization influenced by the tourism sector. Tourism is therefore strategic for Benidorm which currently receives 6 million visitors annually well distributed throughout the year. Characterized by very dry summers and long droughts, the city is based on a «sun and beach» tourist model currently expanding in order to attract other kinds of tourists (e.g. business conventions). Its urban model is considered environmentally efficient in regard to energy, water and land use, and less dependent on private transport. Most importantly, part of the wastewater from urban and tourism uses may be used by farmers through an interesting exchange of waters of different qualities.

However new urban forms and tourist amenities in the vicinity of Benidorm are emerging such as golf courses, aquatic parks, swimming pools etc and taking a much more sprawled form. Contrary to Venice, Benidorm may experience occasional problems of supply (although not in the last decade) but wastewater treatment services cover 100 per cent of the flows. Moreover, the hydrosocial cycle of Benidorm shows an important presence of private interests, especially regarding supply.

\section{CONCLUDING REMARKS}

This study has attempted to explore different approaches to the analysis of water in urban environments particularly those in which tourism is the main activity.

Co-evolutionary relations, complexity and new governance challenges related to water resources in these contemporary urban environments have been discussed in the first part of the study. Then, the paper has moved to present several categorizations of the flow of water in cycles, beginning with the hydrological cycle and continuing with the urban water cycle, urban water metabolism and finally the hydrosocial cycle. In each of these categorizations, the social and political components of water flows are increasingly made more evident. In this sense, the paper has emphasized the importance to explore hydrosocial cycles under the framework provided by the Urban Political Ecology, particularly in cities characterized by urbanization and tourism, extending therefore, the analysis to physical (hydrological) and social (human activities and economical and cultural conditions of power and control) flows of water. In light of the urban hydrosocial concept the cases of cities like Venice and Benidorm, may reveal how these physical and social flows are engaged in shaping and reproducing new urban and tourist hydrosocial configurations (Swyngedouw, 2004, 2012). Moreover, these flows may disclose how they are or have been influenced by different models (private and public) water governance. Its evaluation may also 
help to shed light on how water resources in these urban environments may be governed and managed in the present and future years.

Overall, this combined analysis can provide new insights for geographers, planners and those working in urban water studies and related disciplines interested in the interactions between water and governance both locally and globally.

\section{ACKNOWLEDGEMENT}

I would like to express sincere thanks to David Sauri, Universitat Autònoma de Barcelona; Erik Swyngedouw, University of Manchester; and Giorgos Kallis, Institute for Environmental Science and Technology, for their helpful comments on the preliminary version of this work and to expand and deepen the arguments of this paper.

\section{REFERENCES}

ALBERTI, M. (1999): "Modeling the urban ecosystem: a conceptual framework", Environment and Planning B: Planning and Design, 26(4), pp. 605-630.

ALBERTI, M. (2008): Advances in Urban Ecology: Integrating Humans and Ecological Processes in Urban Ecosystems. Ed. Springer. New York.

AMORES, M. J, MENESES, M., PASQUALINO, J., ANTÓN, A. \& CASTELLS, F. (2013): "Environmental assessment of urban water cycle on Mediterranean conditions by LCA approach", Journal of Cleaner Production, $\mathrm{n}^{\circ}$ 43, pp. 84-92.

BAKKER, K. (2005): "Neoliberazing Nature? Market Environmentalism in water Supply in England and Wales". Annals of the Association of American Geographers, 95(3), pp. 542-565.

BARDATI, D. (2009): "Water, science and humans: Exploring the hydrosocial cycle in the St. Francis River Watershed", Northeastern Geographer, n 1, pp. 45-58.

BARNES, J. (2012): Mixing Waters: The Reuse of Agricultural Drainage Water in Egypt. Geoforum.

BARRACÓ, H., PARÉS, M., PRAT, A. \& TERRADAS, J. (1999): 1985-1999. Ecologia d'una ciutat. Comissió de Medi Ambient i Serveis Urbans de l'Ajuntament de Barcelona. Barcelona.

BATTY, M. \& MARSHALL, S. (2012): The origins of complexity theory in cities and planning. In: Portugali, J., Meyer, H. \& Stolk, E. Ed. Complexity Theories of Cities Have Come of Age. pp. 24 - 47). Springer Verlag. Berlin and Heidelberg.

BANISTER, J. M. (2013): "Are you Wittfogel or against him? Geophilosophy, hydro-sociality, and the state", Geoforum.

BLUE PLAN (2008): The Blue Plan's Sustainable Development Outlook for the Mediterranean. Sophia Antipolis, Plan Bleu. France.

BOELENS, R. (2013): "Cultural politics and the hydrosocial cycle: Water, power and identity in the Andean highlands", Geoforum.

BOULEAU, G. (2013): "The co-production of science and waterscapes: The case of the Seine and the Rhône Rivers, France", Geoforum.

BOURBLANC, M. \& BLANCHON, D. (2013): "The challenges of rescaling South African water resources management: Catchment Management Agencies and interbasin transfers", Journal of Hydrology.

BRATINA JURKOVIČ, N. (2011): Landscape management methodologies: A synthesis report of thematic studies. Priority Actions Programme, Split.

BRILLY, M., RUSJAN S., \& VIDMAR A. (2006): "Monitoring the impact of urbanization on the Glinscica stream", Physics and Chemistry of the Earth, 31(17), pp. 1089-1096.

BUDDS, J. (2008): Whose scarcity? The hydrosocial cycle and the changing waterscape of La Ligua River Basin, Chile. In: Goodman, M., Boykoff, M., Evered, K. (Eds.), Contentious Geographies: 
Environmental Knowledge, Meaning, Scale. Ashgate Studies in Environmental Policy and Practice. Ashgate Publishing Limited, Aldershot, pp. 59-78.

BUDDS, J. (2009): "Contested H2O: science, policy and politics in water resources management in Chile", Geoforum n 40(3), pp. 418-430.

BUDDS, J. \& HINOJOSA, L. (2012): "Restructuring and Rescaling Water Governance in Mining Contexts: The Co-Production of Waterscapes in Peru", Water Alternatives, 5(1), pp. 119-137.

BURY, J. MARK, B. G., CAREY, M. YOUNG, K. R., MCKENZIE, J. M., BARAER, M., FRENCH, A. \& POLK, M. K. (2013): "New Geographies of Water and Climate Change in Peru: Coupled Natural and Social Transformations in the Santa River Watershed", Annals of the Association of American Geographers, 103(2), pp. 363-374.

CARRARO, C. (2009): Cambiamenti climatici e strategie di adattamento in Italia. Una valutazione economica. Il Mulino. Bologna.

CASTRO, J. E. (2004): "Urban water and the politics of citizenship: the case of the Mexico City Metropolitan Area during the 1980s and 1990s", Environment and Planning A, n³6, pp. 327-346.

CASTRO, J. E. (2013): "Water is not (yet) a commodity: Commodification and rationalization revisited", Human Figurations. Long-term Perspectives on the Human Condition, $\mathrm{n}^{\circ} 2(1)$.

CLARKE-SATHER, A. (2012): "State development and the rescaling of agricultural hydrosocial governance in semi-arid Northwest China", Water Alternatives, 5(1), pp. 98-118.

COOK, I. R. \& SWYNGEDOUW E. (2012): Cities, Social Cohesion and the Environment: Towards a Future Research Agenda. Urban Studies, 49(9), pp. 1959-1979.

DE VRIES, B. \& GOUDSBLOM J. (2002): Mappae Mundi. Humans and their Habitats in a Long-Term Socio- Ecological Perspective. Myths, Maps, and Models. Ed. Amsterdam University Press. Amsterdam.

DUVIGNEAUD, P. \& DENAEYER-DE SMET. S. (1977): "L'écosystème urbain bruxellois. In Productivité en Belgique, edited by P. Duvigneaud and P. Kestemont. Traveaux de la Section Belge du Programme Biologique International, Brussels. Ed. Duculot. Paris.

EUROPEAN COMMISSION JOINT RESEARCH CENTRE (2002): Towards an urban atlas: Assessment of spatial data on 25 European cities and urban areas. Environmental issue report $\mathrm{n}^{\circ} 30$, European Environmental Agency, Copenhagen.

EUROPEAN ENVIRONMENT AGENCY (EEA) (2006): Urban Sprawl in Europe. The ignored challenge. EEA Report 10. European Environment Agency. Copenhaguen.

FERNÁNDEZ, S. (2013): "Much Ado About Minimum Flows... Unpacking indicators to reveal water politics", Geoforum.

FLETCHER, T. D., ANDRIEU, H. \& HAMEL, P. (2013): "Understanding, management and modelling of urban hydrology and its consequences for receiving waters: A state of the art", Advances in Water Resources, n51, pp. 261-279.

FLEURY, M. A. (2003): Unearthing Montreal's Municipal Water System Amalgamating and Harmonizing Urban Water Services, FES Outstanding Graduate Student Paper Series, 8(7), pp. 59.

FONSTAD, M. A. (2013): "Geographies of Water", Annals of the Association of American Geographers, $\mathrm{n}^{\circ} 103(2)$, pp. 251-252.

GANDY, M. (1997): "The making of a regulatory crisis: restructuring New York City's water supply", Transactions of the Institute of British Geographers, $\mathrm{n}^{\circ} 22$, pp. 338-358.

GANDY, M. (2008): "Landscapes of disaster: water, modernity, and urban fragmentation in Mumbai", Environment and Planning A, n 40, pp. 108-130.

GASPAR, J. (1984): Urbanization: growth, problems and policies. In Southern Europe Transformed: Political and Economic Change in Greece, Italy, Portugal and Spain, A Williams. Ed. Harper and Row publishers London, pp. 208-235. 
GLOBAL WATER PARTNERSHIP (2000): Towards Water Security: A Framework for Action, GWP, March. GÖSSling S., PEETERS, P., HALl, M., CERON, J. P., DUBOIS, G., LEHMANN, L. V., SCOTT D., (2012): "Tourism and water use: Supply, demand, and security. An international review", Tourism Management, n³3(1), pp. 1-15.

GÖSSLING, S. \& HALL, C. M. (2006): Tourism \& Global Environmental Change. Ed. Routledge, London. GOUDIE, A. (2000): Hydrology. Dictionary of physical geography, Ed. David S. G. Thomas and Andrew Goudie, Blackwell. Oxford, pp. 256-257.

GOUDSBLOM, J. (1992): Fire and Civilization. Ed. Allen Lane. London.

GRIMM, N. B., GROVE, J. M., PICKETT, S. T. A. \& REDMAN, C. L. (2000): "Integrated Approaches to Long-Term Studies of Urban Ecological Systems", BioScience, 50(7), pp. 571-584.

HELD, I. M., \& SODEN, B. J. (2006): "Robust Responses of the Hydrological Cycle to Global Warming", Climate, 19, pp. 5686-5699.

HOFA, A., \& SCHMITT, T. (2011): "Urban and tourist land use patterns and water consumption: Evidence from Mallorca, Balearic Islands", Land Use Policy, 28, pp. 792-804.

JONES, J. (1997): Global Hydrology: Processes, Resources and Environmental Management. Ed. Longman, Harlow.

KAIKA, M. (2005): City of Flows: Modernity, Nature, and the City. Ed. Routledge, London and New York.

KAIKA, M. (2006): "The political ecology of water scarcity: the 1989-1991 Athenian drought", pp. 150-164. In KAIKA, M., HEYNEN, N. \& SWYNGEDOUW, E. 2006. In the Nature of Cities: Urban Political Ecology and the Politics of Urban Metabolism. Questioning Cities. Ed. Routledge, New York.

KALLIS, G. (2010): "Coevolution in water resource development. The vicious cycle of water supply and demand in Athens, Greece” Ecological Economics, 69(4), pp. 796-809.

KEIL, R. \& YOUNG, D. (2001): Water, Suburbs and Development: Unearthing the Toronto Region's Water Regime. Toronto: Faculty of Environmental Studies, Research Development Fund 2001.

KENNEDY, C., CUDDIHY, J. \& ENGEL YAN, J. (2007): "The changing metabolism of cities", Journal of Industrial Ecology, ${ }^{\circ} 11$, pp. 43-59.

KENNEDY, C., PINCETL, S. \& BUNJE, P. (2011): "The study of urban metabolism and its application to urban planning and design", Environmental Pollution, n 159, pp. 1965-1973.

KENT, M., NEWNHAM, R. \& ESSEX, S. (2002): "Tourism and sustainable water supply in Mallorca: a geographical analysis". Applied Geography, n²2, pp. 351-374.

LARRABEITI RODRÍGUEZ, J. J. (2013): "Producción de nuevas «naturalezas urbanas» y sus consecuencias sobre el consumo de agua en alicante", Investigaciones geográficas, nº 58, pp. 143-170.

LAST, E. \& MACKAY, R. (2010): City Water Balance. New tool for scoping Integrated Urban Water Management Options. IAHR European Congress.

LEE, J., PAK, G., YOO, C., KIM, S. \& YOON, J. (2010): "Effects of land use change and water reuse options on urban water cycle", Environmental Science, 22(6), pp. 923-928.

LINTON, J. (2008): "Is the hydrologic cycle sustainable? A historical-geographical critique of a modern concept", Annals of the Association of American Geographers, n 98(3), pp. 630-649.

LINTON, J. (2010): What is Water? The History of a Modern Abstraction. Ed. UBC Press. Vancouver.

LOFTUS, A. (2006): "The metabolic processes of capital accumulation in Durban's waterscape", pp. 165-182. In KAIKA, M., HEYNEN, N. \& SWYNGEDOUW, E. 2006. In the Nature of Cities: Urban Political Ecology and the Politics of Urban Metabolism. Questioning Cities. Ed. Routledge, New York.

MAIDMENT, D. R. (1993): Handbook of Hydrology. Ed. McGraw-Hill Inc., New York: pp. 1-3. 
MAKROPOUlOS, C. K., NATSIS, K., LIU, S., MITTAS, K. \& BUTLER, D. (2008): "Decision support for sustainable option selection in integrated urban water management", Environmental Modelling and Software, 23(12), pp. 1448-1460.

MARIOTTI, A., STRUGLiA, M. V., ZENG, N. \& LAU, K. M. (2002): "The Hydrological Cycle in the Mediterranean Region and Implications for the Water Budget of the Mediterranean Sea", Climate, $\mathrm{n}^{\circ} 15$, pp. 1674-1690.

MCPHERSON, M.B. \& SCHNEIDER, W. J. (1974): "Problems in modeling urban watersheds", Water Resources, 10(3), pp. 434-440.

MEHMOOD, A., (2010): "On the History and Potentials of Evolutionary Metaphors in Urban Planning", Planning Theory, 9(1), pp. 63-87.

MINX, J., CREUTZIG, F., MEDINGER, V., ZIEGLER, T., OWEN, A. \& BAIOCCHI, G. (2010): Developing a Pragmatic Approach to Assess Urban Metabolism in Europe. European Environment Agency, Stockholm Environment Institute.

MITCHELL, V. G. (2006): “Applying Integrated Urban Water Management Concepts: A Review of Australian Experience", Environmental Management, n³7, pp. 589-605.

MITCHELl, V. G., MEIN, R. G., \& MCMAHON, T. A. (2001): "Modelling the Urban Water Cycle", Environmental Modelling \& Software, 16(7), pp. 615-629.

MOHAMED, E. M., MAHGOUB, N., VAN DER STEEN, P., ABU-ZEID, K. \& VAIRAVAMOORTHY, K. (2010): "Towards Sustainability in Urban Water: A Life Cycle Analysis of the Urban Water System of Alexandria City, Egypt", Journal of Cleaner Production, 18, pp. 1100-1106.

MOLLINGA, P. P. (2013): "Canal irrigation and the hydrosocial cycle The morphogenesis of contested water control in the Tungabhadra Left Bank Canal, South India", Geoforum.

MUNOZ, F. (2003): "Lock living: urban sprawl in Mediterranean cities", Cities, 20(6), pp. 381-385.

NEWMAN, P. (1999): "Sustainability and cities: extending the metabolism model", Landscape and Urban Planning, 44(4), pp. 219-226.

NORMAN, E. S. (2012): "Cultural Politics and Transboundary Resource Governance in the Salish Sea." Water Alternatives, 5(1), pp. 138-160.

NORMAN, E. S., BAKKER, K. \& COOK, C. (2012): "Introduction to the themed section: Water governance and the politics of scale", Water Alternatives, 5(1), pp. 52-61.

OHMURA, A. \& WILD, M. (2002): "Is the Hydrological Cycle Accelerating?" Science, 298(5597), pp. 1345-1346.

OKI, T. \& KANAE, S. (2006): "Global Hydrological Cycles and World Water Resources", Science, 313(5790), pp. 1068-1072.

PAGE, S. \& HALL, C. M. (2003): Managing Urban Tourism. Ed. Prentice-Hall. Harlow.

PAP/RAC (1997): Integrated approach to development, management and use of water resources. Priority Actions Programme Regional Activity Centre. Split.

PEÑA GARCÍA, A. (2007): "Una perspectiva social de la problemática del agua Investigaciones Geográficas", Boletín del Instituto de Geografía, n 62, pp. 125-137.

PERRAMOND, E. P. (2012): The politics of scaling water governance and adjudication in New Mexico. Water Alternatives, 5(1), pp. 62-82.

PLAN BLEU, CENTRE D'ACTIVITÉ REGIONAL (PB/CAR) (2003): Les Cahiers du Plan Bleu n.2-mai 2003: Threats to Soils in Mediterranean Countries, Document review, PNEU, PAM and Plan Bleu, Sophia Antipolis.

RAPOPORT, E. (2011): Interdisciplinary perspectives on Urban Metabolism. A review of the literature. UCL Environmental Institute working paper. Development planning unit, UCL. 
RICO AMOROS, A. M., OLCINA CANTOS, J. \& SAURI, D., (2009): "Tourist land use patterns and water demand: evidence from the Western Mediterranean", Land Use Policy, n² 26(2), pp. 493-501.

RIND, D., ROSENZWEIG, C. \& GOLDBERG R. (1992): "Modelling the hydrological cycle in assessments of climate change", Nature, 358, pp. 119-122.

ROGERS, P. \& HALL, A. (2003): Effective Water Governance. Global Water Partnership Technical Committee, Background Paper n ${ }^{\circ} 7$.

ROZOS, E. \& MAKROPOULOS, C. (2013): "Source to tap urban water cycle modeling", Environmental Modelling \& Software, $n^{\circ} 41$, pp. 139-150.

SWYNGEDOUW, E. (1997): "Power, Nature and the City. The Conquest of Water and The Political Ecology of Urbanization in Guayaquil, Ecuador: 1880-1980", Environment and Planning A, 29(2), pp. 311-332.

SWYNGEDOUW, E. (2005): "Dispossessing H2O: The contested terrain of water privatization", Capitalism Nature Socialism, $\mathrm{n}^{\circ}$ 16(1), pp. 81-98.

SWYNGEDOUW, E. (2004): Social Power and the Urbanization of Water: Flows of Power. Oxford University Press, Oxford.

SWYNGEDOUW, E., MARIA K., \& CASTRO, E. (2002): "Urban water: A political-ecology perspective", Built Environment $n^{\circ} 28$ (2), pp. 124-37.

THORNTHWAITE, C. W. \& MATHER, J. R. (1955): "The water balance", Climatology, n 8(1), p.104.

TIMMERMAN, P. \& WHITE, R. (1997): "Megahydropolis: coastal cities in the context of global environment change", Global Environmental Change, n 7(3), pp. 205-234.

TRUST (2013): TRansitions to the UrbanWater Services of Tomorrow. Deliverable of the working area 3. Available online at: http://www.trust-i.net/

TUAN, Y. F. (1968): The hydrologic cycle and the wisdom of God: A theme in geoteleology. Ed. University of Toronto Press. Toronto.

UNEP/MAP (2012): State of the Mediterranean Marine and Coastal Environment. UNEP/MAP - Barcelona Convention, Athens.

UNEP/MAP/BP/RAC (2009): The State of the Environment and Development in the Mediterranean 2009. United Nations Environment Programme, Mediterranean Action Plan, Blue Plan Regional Activity Centre, Vallbone.

UNEP/MAP-PLAN BLEU (2009): State of the Environment and Development in the Mediterranean, UNEP/ MAP-Plan Bleu. Athens.

UNEP-MAP (2007): Guidelines for Integrated Urban Water System Management in Coastal Areas of the Mediterranean. Vol 1. Principle and Planning, Priority Actions Program - Regional Activity Centre. Athens.

UNESCO-IHP-VI (2006): Urban water cycle processes and interactions. Technical Document in Hydrology. UNESCO Working Series $n^{\circ} 78$, Paris.

UN-HABITAT (2011): Water for cities. Responding to the urban challenge. Final Report. World Water Day 2011. Water and Urbanization. Nairobi.

UN-HABITAT (2012): State of the World's Cities Report 2012/2013: Prosperity of Cities, United Nations Human Settlements Programme (UN-HABITAT). Nairobi, Kenya.

UNITED NATIONS EDUCATIONAL SCIENTIFIC AND CULTURAL ORGANIZATION (UNESCO) - World Water Assessment Programme (WWAP) (2012): Managing Water under Uncertainty and Risk. The United Nations World Water Report 4. Paris.

UNITED NATIONS EDUCATIONAL SCIENTIFIC AND CULTURAL ORGANIZATION (UNESCO) - World Water Assessment Programme (WWAP) (2009): Water in a Changing World. The United Nations World Water Report 3. Ed. UNESCO and Earthscan. Paris and London. 
UNWTO (2012): UNWTO Tourism Highlights. World Tourism Organization (UNWTO) World Tourism barometer. Madrid.

VAN DER BRUGGE, R., \& VAN RAAK, R. (2007): "Facing the adaptive management challenge: insights from transition management", Ecology and Society, 12(2), p. 33.

VAN DER BRUGGE, R., ROTMANS, J. \& LOORBACH, D. (2005): "The transition in Dutch water management", Regional Environmental Change, 5(4), pp. 164-176.

VAN LEEUWEN, C. J., FRIJNS, J., VAN WEZEL, A., VAN DE VEN, F. H. M. (2011): City Blueprints: 24 indicators to assess the sustainability of the urban water cycle. Springer-Verlag.

VIOLI P., \& LORUSSO, A. M. (2011): Effetto Med immagini, discorsi, loghi. Ed. Fausto Lupetti. Bologna.

VOGEL, E. (2012): "Parcelling out the watershed: The recurring consequences of organising Columbia river management within a basin-based territory. Water Alternatives 5(1): 161-190.

WANGA,X., OTTOA, I. M. \& YUB, L. (2013): "How physical and social factors affect village-level irrigation: An institutional analysis of water governance in northern China", Agricultural Water Management, $\mathrm{n}^{\circ} 119$, pp. 10-18.

WHITE, G. F. (1945): Human adjustment to floods. Department of Geography Research n 29, Ed. The University of Chicago, Chicago.

WOLMAN, A. (1965): The metabolism of cities. Scientific American, 213(3), pp. 179-190.

WTM (2007): World travel market "no water no future". From International Center for Responsible Tourism: http://www.icrtourism.org/water.pdf.

ZIMMERER, Z. S. (2011): "The landscape technology of spate irrigation amid development changes: Assembling the links to resources, livelihoods, and agrobiodiversity-food in the Bolivian Andes", Global Environmental Change, 21, pp. 917-934. 